\title{
Statistical evaluation of Ips typographus population density: a useful tool in protected areas and conservation-oriented forestry
}

\author{
Andrzej Borkowski • Rafał Podlaski
}

Received: 16 December 2010/ Accepted: 18 July 2011/Published online: 2 August 2011

(C) The Author(s) 2011. This article is published with open access at Springerlink.com

\begin{abstract}
Ips typographus (Col., Curculionidae, Scolytinae) occurring on Picea abies stems is a species characterised by large fluctuations in population numbers and causing frequent outbreaks. In protected areas, I. typographus is regarded as a sensitive bioindicator responsive to changes in forest health and vitality. In conservation-oriented forestry, attention is being paid to the ecological value of I. typographus beetles as ecosystem engineers and keystone species, driving forest natural regeneration and conversion. Despite many publications devoted to I. typographus, no accurate method for estimating the population density of this species has been developed. The objective of this study was to develop a statistical method for estimating I. typographus population density that enables calculation of estimation errors. The proposed method consists of two parts: tree-level analyses and stand-level analyses. Part one allows calculation of the total density of I. typographus infestation of each of $P$. abies selected stem (after selecting sample windfalls), part two allows estimation of the mean total infestation density of the stem in the area investigated. Linear regression functions were applied to part one and survey sampling to part two. The method is only marginally invasive because it involves debarking of one $0.5 \mathrm{~m}$-long stem section on maximum $50 \mathrm{P}$. abies windfalls (trap trees can optionally be used). The developed method was employed to assess I. typographus population density in the Świętokrzyskie Mountains in Central Poland in an area of ca. 4,000 ha. In 2010, in the area investigated, the mean total I. typographus infestation density of the $P$. abies stem was 440.6 maternal galleries $/ \mathrm{m}^{2}$ (from 358.7 to 522.6 maternal galleries $/ \mathrm{m}^{2}$ with $\alpha=0.05$; the relative error of estimation was $18.6 \%$ ). The examined I. typographus population was in a progradation phase. The proposed method can be used in nature reserves, national parks and managed forests, mainly for scientific purposes.
\end{abstract}

\footnotetext{
A. Borkowski

Department of Ecology and Environment Protection, Institute of Biology, Jan Kochanowski University, ul. Świętokrzyska 15, 25-406 Kielce, Poland

R. Podlaski $(\bowtie)$

Department of Nature Conservation, Institute of Biology, Jan Kochanowski University, ul. Świętokrzyska 15, 25-406 Kielce, Poland e-mail: r_podlaski@pro.onet.pl
} 
Keywords Ips typographus $\cdot$ Statistical model $\cdot$ Population density estimation · Keystone species · Conservation · Forest management

\section{Introduction}

The spruce bark beetle, Ips typographus (Col., Curculionidae, Scolytinae), is an important insect species of Picea abies in Europe. The estimation of I. typographus population density is of high theoretical and practical significance for nature conservation and forestry. I. typographus occurs almost in any stand with $P$. abies and is a species particularly responsive to changes in forest health and vitality (Grodzki 2004; Seidl et al. 2008, 2009; Grodzki et al. 2010). These two elements allow to use I. typographus as a bioindicator species. In the forests where $P$. abies provenances unadjusted to the site conditions have been introduced and in the forests exposed to the negative impact of various factors, mainly anthropogenic, the numbers of this insect species increase. Depending on a complex of interacting factors, changes in the number of I. typographus range from minor fluctuations to the occurrence of a small- and large-area outbreaks (Dutilleul et al. 2000; Wichmann and Ravn 2001; Bouget and Duelli 2004; Eriksson et al. 2005, 2007). Significant changes in the I. typographus population numbers indicate the need to modify forest management methods, but first of all they are the main factor deciding about the commencement and extent of protective measures to be taken.

The issue of interference into the forest ecosystem is very complex and the question is always asked whether the commencement of active protection is necessary. The discussion on the above issue is very difficult and should always take into account the characteristics of a given stand. The conservation-oriented forestry, thoroughly considers the important problems: (1) whether to intervene actively into the ecosystem, reducing the I. typographus numbers and (2) whether the outbreaks of this insect species can be regarded as a factor causing the initiation of natural regeneration and/or conversion. However, it should be noted that all these considerations and discussions may have sense only if we know the data on the population dynamics of I. typographus in the stand.

In spite of many publications devoted to I. typographus, including a partial review made by Wermelinger (2004) and Sun et al. (2006), no effective method for estimating the population density of this species has been developed. Generally, there are three groups of methods of indirect estimation of the I. typographus population density using: (1) pheromone traps, (2) infested stems (windfalls or trap trees) and (3) the quantity of trees infested. For all the above-mentioned methods respectively the assumption was made that (1) the number of insects caught, (2) the number of galleries and (3) the quantity of trees infested are directly proportional to the actual I. typographus population size. The methods employing the trees infested are least accurate. The accuracy of the methods using pheromone traps and infested stems is the greater the more insects of a given population are caught or infest the $P$. abies stems. The trapping effectiveness varies and is often lower compared to 'natural traps' (Wichmann and Ravn 2001; Wermelinger 2004; Faccoli and Stergulc 2008). In addition, the installation of pheromone traps is expensive, it requires constant inspection, and in areas under strict protection, it is an 'artificial' interference into the forest ecosystem (Grodzki 2007; Grodzki et al. 2008). In turn, counting I. typographus galleries on $P$. abies stems is the major limitation of using 'natural traps'. The counting of galleries of this insect species is very labour-intensive because it requires precise debarking of tree stems combined with the simultaneous identification of galleries. Thus, in the 
majority of studies, the estimation of the density of galleries is restricted to small plates of bark collected from various parts of stems (Yamaoka et al. 1997; Jakuš 1998; Göthlin et al. 2000; Grodzki 2004; Hedgren and Schroeder 2004; Erbilgin et al. 2006; Eriksson et al. 2005, 2006, 2008). Regrettably, the methods for estimating the I. typographus population density presented in the above mentioned studies are not based on statistical methods; they do not allow calculation of estimation errors and can therefore be very inaccurate.

In order to estimate the population density of I. typographus using infested stems, statistical methods should be applied to estimate: (1) the total density of I. typographus infestation of $P$. abies stems (tree-level); (2) the population density of I. typographus in the area investigated (stand-level). The development of the statistically-based method less interfering into the forest ecosystem and possibly less labour-intensive would allow quick and accurate estimation of the population density of I. typographus. This type of method could be applied to the most valuable natural areas placed under strict protection. Placing a larger number of pheromone traps and total debarking of dead trees in reserves and national parks is generally not possible. On the other hand, an analysis of the population dynamics of I. typographus in managed forests is an indispensable tool for carrying out silvicultural treatments, improvement of forest management methods and implementation of conservation-oriented forestry.

The outbreaks of I. typographus have been observed for a long time, in all Central and Northern European countries (e.g. Eidmann 1992; Peltonen 1999; Schröter 1999; Wichmann and Ravn 2001; Grodzki 2004; Gilbert et al. 2005). I. typographus mainly attacks weakened and fallen trees but; when it occurs in large numbers, it may also infest healthy trees after overcoming their defence mechanisms (e.g. Christiansen et al. 1987; Lieutier 2004). Wind-fallen trees reveal little or no resistance to beetle attacks allowing successful colonisation of their stems at low densities and thereby avoiding strong intraspecific competition (Anderbrant 1990). Hence, windfalls may result in a surplus of the breeding material, which in turn may lead to population outbreaks and subsequent attacks on standing healthy trees (e.g. Bakke 1989; Wermelinger et al. 2002). Among all types of forest damage in Europe, in the period 1950-2000, 2-9 million $\mathrm{m}^{3}$ per year of volume of trees infested by bark beetles, mainly I. typographus were removed from the stands (Schelhaas et al. 2003). The scale of the presented phenomenon proves great economic importance of this insect species. In this situation, most published studies on I. typographus deal with damage and prevention of outbreaks in stands (see Wermelinger 2004; Sun et al. 2006). However in recent years, more and more authors draw attention to the ecological value of I. typographus as ecosystem engineers and keystone species, driving forest regeneration and conversion (e.g. Müller et al. 2008). The keystone species have a disproportionately large effect on ecosystems, compared to their abundance or biomass (e.g. Simberloff 1998; Buse et al. 2007).

Due to large density fluctuations and frequent outbreaks of I. typographus, the proposed method for estimating I. typographus population density should be used primarily during the progradation phase when quick and accurate monitoring of the population dynamics of this insect species is especially required. Therefore, work on the method facilitating quick estimation of the population density of I. typographus requires, inter alia, determination of sex structure (in order to detect whether the population of I. typographus is in the progradation phase) and determination of the spatial distribution pattern of galleries on $P$. abies stems (the distribution pattern of galleries determines the choice of an appropriate statistical method). The objective of the study is: (1) the proposal of the statistical evaluation of I. typographus population density using the method consisting of two stages, depending successively on: (a) the estimation of the total density of infestation of P. abies 
stems by I. typographus based on the relationship between the number of galleries of this insect species on the selected stem sections and the total density of infestation of stems (tree-level estimation), (b) the estimation of the population density of I. typographus for the area investigated, using $P$. abies windfalls (stand-level estimation) and (2) validation of the method.

\section{Study area}

In 2007, field surveys of selected stands with P. abies were conducted in the Carpathians, Sudetes and Świętokrzyskie Mountains. The aim of the surveys was to identify stands that met the following conditions: (1) were of the local P. abies provenance, (2) grew on a suitable site, (3) in which the I. typographus population was in the progradation phase. Such stands were found, inter alia, in the Świętokrzyskie Mountains (Central Poland). The stands were established by way of: (1) natural regeneration and (2) artificial regeneration from seeds representing local $P$. abies populations. In the Świętokrzyskie Mountains, $P$. abies is the species occurring in upland habitats in mixed forests with Abies alba and Pinus sylvestris. For economic reasons, no large-scale clear-cuts were applied in the area investigated nor were $P$. abies seeds imported on a commercial scale from outside the Świętokrzyskie Mountains (Barański and Krysztofik 1978). Preferences were given to the natural regeneration or planting stock obtained from the existing local nurseries. It should be remembered that the road network in that area began to develop as late as in the fifties of the twentieth century. In the nineteenth and twentieth century, clear-cuts over large areas in the Carpathians and Sudetes were commonplace and the planting stock produced from imported seeds, inter alia, from Austria and Germany was widely used.

The field work was carried out in the Klonowskie Mountain range in the Świętokrzyskie Mountains $\left(50^{\circ} 55^{\prime}-51^{\circ} 00^{\prime} \mathrm{N}, 20^{\circ} 40^{\prime}-20^{\circ} 54^{\prime} \mathrm{E}\right.$; $250-350 \mathrm{~m}$ above sea level). The meteorological data obtained over the period $1999-2007$ from the local weather station $\left(50^{\circ} 53^{\prime} \mathrm{N}\right.$, $21^{\circ} 02^{\prime} \mathrm{E} ; 513 \mathrm{~m}$ above sea level) show that the annual mean temperature was $+8.5^{\circ} \mathrm{C}$. The mean temperature in January was $-1.2^{\circ} \mathrm{C}$, and in July it reached $+15.0^{\circ} \mathrm{C}$. The annual mean precipitation was $582 \mathrm{~mm}$. The growing season (the number of days with the daily mean temperature above $5^{\circ} \mathrm{C}$ ) lasts from 1-5 April to 24-30 October. South-west and westerly winds prevail in this area. They sometimes are very strong.

The stands investigated were growing on an upland mixed-forest site and were composed of the following tree species: about $40 \%$ of $P$. abies, aged $80-90$ years; about $40 \%$ of A. alba, aged 100-120 years; and about $20 \%$ of P. sylvestris, aged $80-90$ years. In the Świętokrzyskie Mountains, in the twentieth century, only in the 1920s the outbreak of I. typographus has been reported (Mazur 2001). An increased occurrence of I. typographus has been observed since 2007 in P. abies stands of the Klonowskie Mountain in an area of about 4,000 ha; for example, volume of trees infested by I. typographus and removed from the part of area investigated (Brzezinki forest section) was $136 \mathrm{~m}^{3}$ in 2006 and $433 \mathrm{~m}^{3}$ in 2007 (data supplied by the Forest Inspectorate in Zagnańsk).

\section{Method for estimating I. typographus population density}

The proposed method consists of two parts: tree-level analyses and stand-level analyses. Part one allows estimation of the total infestation density of P. abies stems by I. typographus, the part two allows estimation of the population density of I. typographus in the 
area investigated. After applying tree-level analyses we are provided with knowledge about the total infestation density of each of examined stem; after applying stand-level analyses we gain knowledge about the mean total infestation density of the stem in the area investigated.

\section{Tree-level analyses}

In order to develop statistical methods for estimating the total infestation density of $P$. abies stems by $I$. typographus, we used the relationships between the number of maternal galleries of this insect species in selected stem sections and the total infestation density of windfalls.

In May 2008 and 2009, 25 P. abies trees downed by the wind were randomly selected each year (a total of 50 windfalls were selected; their roots retained the contact with the ground). In June 2008 and 2009, roots and branches of each tree were cut off and the trees were measured. Sections measured from the tree base up to the diameter of approximately 7-9 cm in the thinner end of the stem were distinguished on the windfalls: (1) $0.5 \mathrm{~m}$-long sections and (2) sections comprising 10\% stem lengths of fallen trees without tops (Fig. 1). $0.5 \mathrm{~m}$-sections distinguished in such a manner so that the last section also equalled $0.5 \mathrm{~m}$ and the final diameter was within the range of $7-9 \mathrm{~cm}$. Then, the trees were measured for: (1) the diameter at breast height and diameter over bark in the mid-length of each stem section, (2) the initial diameter, (3) the final diameter and (4) the total length and the length of the lying tree without top.

The sex ratio and the number of I. typographus maternal galleries were calculated using the method of entomological section-based analysis. It consisted in the removal of bark plates from the successive $0.5 \mathrm{~m}$-long stem sections. To avoid bark damage during its removal the circumference, sides and upper part were incised in the successive sections of the stem. For each $0.5 \mathrm{~m}$-long section two bark pieces from the upper area and one bark piece from the bottom area of the stem were taken. The bark pieces collected from the stems were transported to the laboratory on the same day. In addition to the I. typographus maternal galleries (1) the number of galleries of Pityogenes chalcographus and

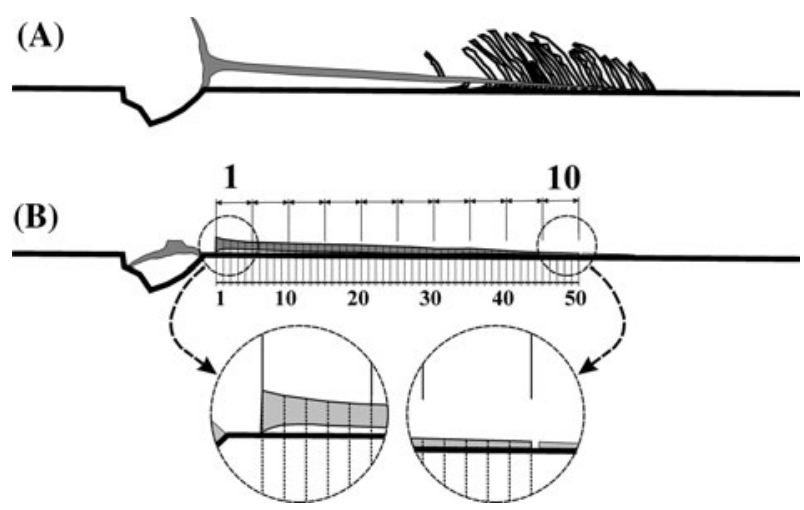

Fig. 1 a $P$. abies windfall. b The windfall after branch and top removal; marked are the boundaries of fifty $0.5 \mathrm{~m}$-long sections and the ten $10 \%$ stem length sections (length of a fallen tree without top is $25 \mathrm{~m}$, diameter at the thinner end is $8 \mathrm{~cm}$ ) 
Ips amitinus, (2) the number of maternal galleries of Hylurgops palliatus and Dryocoetes autographus, (3) the number of entrances of Xyloterus lineatus to wood were counted.

The stem form of a coniferous tree can be expressed by Kunze's equation (Inoue 2006):

$$
r=\sqrt{b l^{c}}
$$

where $r$ is stem radius, $l$ is stem length from tree tip, $b$ and $c$ are coefficients. The stem surface area $s$ of the tree can be computed by the following formula:

$$
s=2 \pi \int_{0}^{h} r \sqrt{1+\left(\frac{d r}{d l}\right)^{2}} d l
$$

where $h$ is the length of the lying tree without top.

The total colonisation density of each $P$. abies stem was calculated: (1) after summing of I. typographus maternal galleries in all $0.5 \mathrm{~m}$-long sections and (2) after calculating the stem surface area.

One-way ANOVA followed by post hoc Fisher's least significant difference (LSD) procedure $(\alpha=0.05)$ for multiple comparisons was used to analyse differences in $I$. $t y$ pographus attack densities in individual sections of windfalls.

To determine the relationships between the number of I. typographus maternal galleries in selected $0.5 \mathrm{~m}$-long stem sections and the total density of stem infestation the analyses of correlation and regression were used. The following linear regression functions were employed:

$$
D_{\mathrm{ts}}=a_{0 k}+a_{1 k} n I t_{k}
$$

where $D_{\mathrm{ts}}$ is the total density of stem infestation (number of maternal galleries $/ \mathrm{m}^{2}$ ) in the whole $P$. abies windfall; $n I t_{k}$ is a number of $I$. typographus maternal galleries in distinguished $0.5 \mathrm{~m}$-long stem section $k(k=1,2, \ldots, 50)$ in the $P$. abies windfall; $a_{0 k}$, and $a_{1 k}$ are parameters of linear functions for the section $k$.

For each stem section calculations were made, including: (1) parameters of regression functions $\left(a_{0 k}, a_{1 k}\right)$, (2) the coefficient of correlation $\left(r_{k}\right)$, (3) the mean relative error of estimation $\left(s w_{k}\right)$ :

$$
s w_{k}=\sqrt{\frac{1}{n_{k}-2} \sum_{w=1}^{n_{k}}\left(D_{\mathrm{ts}_{w}}-a_{0 k}-a_{1 k} n I t_{k_{w}}\right)^{2}} \frac{1}{\bar{D}_{\mathrm{ts}}}
$$

where $\bar{D}_{\mathrm{ts}}=\frac{1}{n_{k}} \sum^{n_{k}} D_{\mathrm{ts}_{w}} ; D_{\mathrm{ts}_{w}}$ is the total density of stem infestation (number of maternal galleries $/ \mathrm{m}^{2}$ ) in ${ }^{n}$ the whole P. abies windfall $w ;$ It $_{k_{w}}$ is a number of I. typographus maternal galleries in distinguished $0.5 \mathrm{~m}$-long stem section $k(k=1,2, \ldots, 50)$ in the $P$. abies windfall $w ; \bar{D}_{\mathrm{ts}}$ is the mean total infestation density of the windfall (tree-level); $n_{k}$ is a number of windfalls which have the section $k$.

In total, calculations were made for 50 functions (sections from 1 st to 50 th). For the latter 50th section, the calculations involved 20 windfalls (20 windfalls without tops had the length of at least $25 \mathrm{~m}$ ). The parameters of regression functions were estimated by the least square method. After the calculations had been completed, the best functions were selected, namely those for which the correlation coefficient values were highest and the mean relative errors of estimation lowest. The analyses were carried out using Mathematica 5 (Wolfram 2003) and Statistica 6.1 (StatSoft 2004). 
Stand-level analyses

\section{Background}

The procedure is dependent on the number of trees downed by the wind in winter and spring in a given year, as well as on the size of the area investigated. While assessing the I. typographus population density, field inspections and assessment of the number of windfalls in late winter and early spring should be carried out in the first place. Three possibilities were distinguished:

(1) the number of windfalls is too small (there are less than 30 windfalls in the area investigated) - an additional certain number of trap trees can be randomly located within the area investigated so that the total number of windfalls and trap trees was at least 30 P. abies stems;

(2) the number of windfalls is appropriate (the whole population of windfalls consists of about 30-50 P. abies stems in the area investigated) - the research should be extended to the whole population of windfalls (Fig. 2);

(3) the number of windfalls is very large (the whole population of windfalls consists of more than $50 \mathrm{P}$. abies stems in the area investigated; in most cases it is the state after the occurrence of strong winds when the number of windfalls is much greater than 50 stems; often the $P$. abies trees downed by the wind form a population of hundreds of trees)-the research should cover a sample representative of the entire population of windfalls (Fig. 3).

The population under study consists of: (1) all trees downed by the wind in winter and spring in a given year in the area investigated, including additionally set trap trees (case 1) or (2) all trees downed by the wind in winter and spring in a given year in the area investigated (case 2 and 3).

\section{Evaluation of I. typographus population density}

Depending on the size of the area investigated and the number of windfalls, the population size of I. typographus is estimated differently.

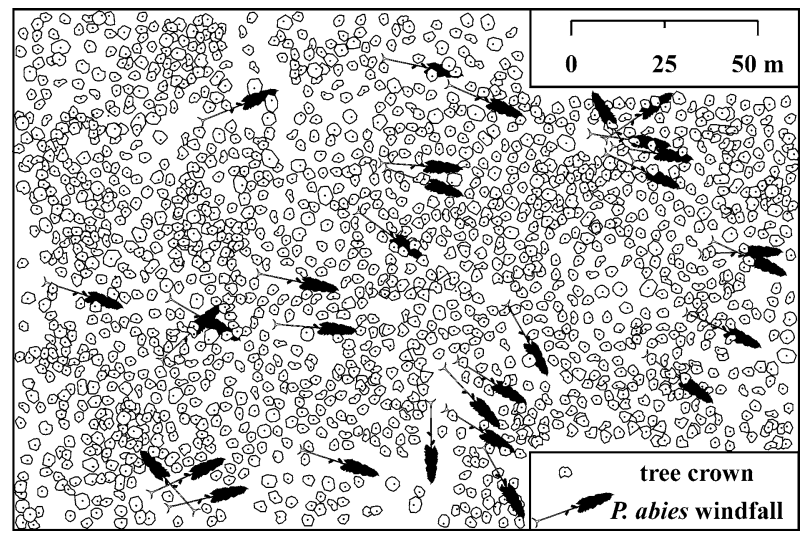

Fig. 2 Example of the use of the small-area method. In the area investigated, the total population of $P$. abies windfalls consists of 30 stems - the research should embrace the entire population of the windfalls 


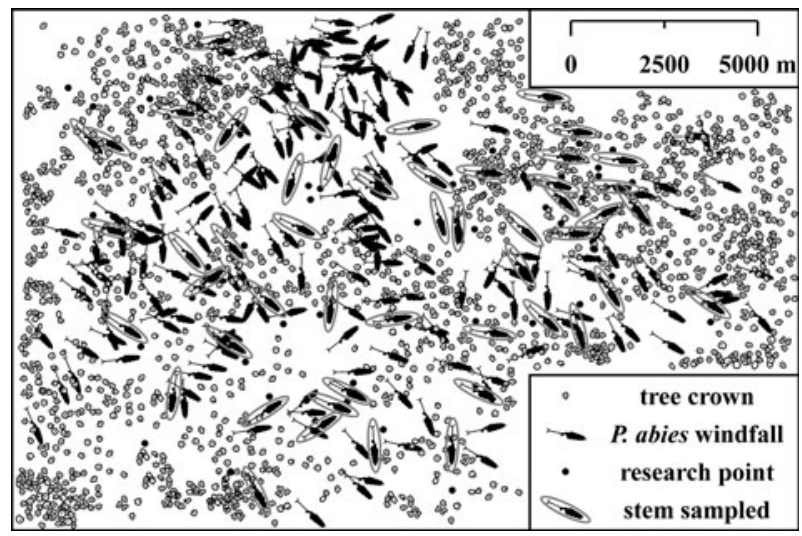

Fig. 3 Example of the use of the large-area method. In the area investigated, the total population of $P$. abies windfalls is significantly larger than 50 stems - the research should embrace a representative sample for the entire population of windfalls. Research points are distributed randomly; in the surroundings of each research point one windfall representing the population investigated is selected (a total of 50 windfalls was randomly chosen). Symbols (tree crown, $P$. abies windfall, research point and stem sampled) are drawn not to a scale

The small-area method (the number of all windfalls is usually lower than or equal to 50) After selecting windfalls and possibly trap trees (depending on the earlier presented cases), one should: (1) debark only one, half-meter section and count the I. typographus maternal galleries on each selected $P$. abies stem, (2) calculate the total density of infestation of each of $P$. abies stem by $I$. typographus using an appropriate function and (3) calculate the mean total infestation density of the stem for the area under investigation (using all investigated stems).

The large-area method (the number of all windfalls is usually significantly larger than 50) In the case of the large-area method, survey sampling should be used to select a representative sample for the whole population. The $P$. abies windfall belonging to the examined population is a statistical unit. The total I. typographus infestation density of the $P$. abies windfalls' stems is an assessed characteristic. The mean total I. typographus infestation density of the $P$. abies stem in the area investigated is a subject to estimation.

A windfall sample is selected using simple random sampling without replacement (SRSWOR) (Thompson 2002). To this end, a coordinate system is marked on the general management map with a scale of 1:5,000 where the investigated area is located. A network formed by the centres of the intervals measured on the $x$ and $y$ axis is used (Podlaski 2005). The length of the intervals depends on a maximum density of windfalls forming the population under investigation. The first step is to sample the coordinates of the research points, and to trace them out in the forest (Fig. 3). The second step is to select windfalls. In the surroundings of each research point, one windfall representing the population investigated is selected. The numbers of research points and sample windfalls depend on the accuracy of the work. It is recommended to select a sample consisting of at least 50 windfalls. If there is no windfall in the surroundings of a given research point, an additional research point should be selected according to the presented procedure. After adding research points, it is checked whether all selected windfalls are distributed randomly. To this aim, Ripley's K-function is used (e.g. Ripley 1981). 
After the sample has been selected one should: (1) debark only one half-meter section and count the maternal galleries of I. typographus on each selected $P$. abies sample stem, (2) calculate the total density of infestation of each of $P$. abies sample stem by $I$. typographus using an appropriate function and (3) estimate of the mean total infestation density of the stem in the area under investigation-calculate the unbiased estimator of the mean and confidence intervals using all sample stems.

In SRSWOR, the unbiased estimator of the mean is (Thompson 2002):

$$
\overline{\bar{D}}_{\mathrm{ts}}=\frac{1}{n} \sum_{i=1}^{n} D_{\mathrm{ts}_{i}}
$$

where $\overline{\bar{D}}_{\text {ts }}$ is the mean total infestation density of the windfall (stand-level); $n$ is a number of all windfalls in a sample; $D_{\mathrm{ts}_{i}}$ is the total density of infestation (number of maternal galleries $/ \mathrm{m}^{2}$ ) of the sample windfall $i$; calculated using an appropriate linear regression function (see Eq. 3).

To estimate the confidence interval for the mean total infestation density of the windfall $\left(\overline{\bar{D}}_{\text {ts }}\right)$ using a sample consisting of at least 50 windfalls, in SRSWOR, a scheme with the normal distribution is used (Cochran 1977). To compute the lower and upper limits of the confidence interval the following formulae are employed (Cochran 1977):

$$
\begin{aligned}
& H_{1}=\overline{\bar{D}}_{\mathrm{ts}}-u_{1-\alpha / 2} \frac{s d_{\mathrm{ts}}}{\sqrt{n}} \sqrt{\frac{N-n}{N}} \\
& H_{\mathrm{u}}=\overline{\bar{D}}_{\mathrm{ts}}+u_{1-\alpha / 2} \frac{s d_{\mathrm{ts}}}{\sqrt{n}} \sqrt{\frac{N-n}{N}}
\end{aligned}
$$

where $H_{1}$ is the lower limit of the confidence interval; $H_{\mathrm{u}}$ is the upper limit of the confidence interval; $\Phi\left(u_{1-\alpha / 2}\right)=1-\alpha / 2$, for example, for $\alpha$ equal $0.05 u_{1-\alpha / 2}$ is 1.96 , $\Phi-N(0,1), \alpha$-significance level; $s d_{\mathrm{ts}}$ is the standard deviation of total infestation density of all windfalls in the sample; $N$ is a number of all windfalls in the area investigated.

If the $\frac{n}{N}$ value is small, the expression $\sqrt{\frac{N-n}{N}}$ is close to 1 and can be left out; the effectiveness of estimates will depend only on the number of all windfalls in a sample.

The relative error of estimation can be computed by the following formula (Cochran 1977):

$$
\hat{d}_{\mathrm{B}}=\frac{H_{\mathrm{u}}-H_{1}}{2} \frac{1}{\overline{\bar{D}}_{\mathrm{ts}}} 100(\%)
$$

\section{Validation of the proposed method}

To present the proposed method for estimating population density of I. typographus, in 2010, the mean total infestation density of the windfall was estimated in the Klonowskie Mountain range in an area of about 4,000 ha. The large-area method was applied. 50 sample points were selected on the map with a scale of 1:5,000 using SRSWOR. After marking the randomly selected points on the map, they were set in the field. Subsequently, the $P$. abies tree overturned by the wind last winter was located in the surroundings of each set point. The found windfalls were distributed at various distances from the set sample points. The maximum distance between the set sample points and found windfalls was about $200 \mathrm{~m}$. 
Therefore, the coordinates of each windfall were determined, plotted on the map and checked whether all selected windfalls were distributed randomly. The calculations were performed using the software package Spatial Point Pattern Analysis (SPPA) (Haase 1995).

After making sure that all selected windfalls are distributed randomly, in June 2010, bark plates were removed from the 6,7 or 17 th $0.5 \mathrm{~m}$-long stem section in each windfall (counting from the butt-end) and I. typographus galleries and maternal galleries were counted. These three sections were used because in 2008 and 2009, they showed the most significant linear correlations between the number of I. typographus maternal galleries in $0.5 \mathrm{~m}$-long stem sections and the total average density of stem infestation in the whole tree stem (Table 1). Only one section was selected on a given windfall-the one that was best available and easiest to debark.

In the successive stages, the total density of I. typographus infestation of each windfall $\left(D_{\mathrm{ts}}\right)$ was estimated using an appropriate linear regression function (Eq. 3) and the mean total infestation density of the stem for the area under investigation was estimated-the

Table 1 Characteristics of the relationships between the numbers of I. typographus maternal galleries in distinguished $0.5 \mathrm{~m}$-long stem section $k\left(n I t_{k}\right)$ and the total density of infestation (number of maternal galleries $/ \mathrm{m}^{2}$ ) of a $P$. abies windfall $\left(D_{\mathrm{ts}}\right)$ (see also Eq. 3)

\begin{tabular}{|c|c|c|c|c|c|c|}
\hline \multicolumn{2}{|l|}{ Stem section } & \multicolumn{2}{|c|}{ Parameters of linear functions } & \multicolumn{2}{|c|}{$\begin{array}{l}\text { Coefficient of } \\
\text { determination }\end{array}$} & \multirow{2}{*}{$\begin{array}{l}\text { Mean relative } \\
\text { error of estimation } \\
s w_{k}(\%)\end{array}$} \\
\hline From-to $(\mathrm{m})$ & $\begin{array}{l}\text { Section } \\
\text { no. } k\end{array}$ & $a_{0 k}$ & $a_{1 k}$ & $r_{k}^{2}$ & $p_{k}$ & \\
\hline $0.0-0.5$ & 1 & 322.31 & 1.1348 & 0.1870 & 0.064 & 43.20 \\
\hline $0.5-1.0$ & 2 & 156.02 & 1.4011 & 0.4276 & 0.002 & 40.74 \\
\hline $1.0-1.5$ & 3 & 102.25 & 1.5390 & 0.5293 & $<0.001$ & 38.32 \\
\hline $1.5-2.0$ & 4 & 112.72 & 1.5198 & 0.5707 & 0.001 & 34.32 \\
\hline $2.0-2.5$ & 5 & 89.10 & 1.5069 & 0.6147 & $<0.001$ & 36.64 \\
\hline $2.5-3.0$ & 6 & 10.83 & 1.8472 & 0.8459 & $<0.001$ & 20.74 \\
\hline $3.0-3.5$ & 7 & 75.36 & 1.5540 & 0.8640 & $<0.001$ & 18.90 \\
\hline $3.5-4.0$ & 8 & 99.53 & 1.4672 & 0.8304 & $<0.001$ & 22.34 \\
\hline $4.0-4.5$ & 9 & 123.76 & 1.3088 & 0.7598 & $<0.001$ & 28.45 \\
\hline $4.5-5.0$ & 10 & 148.47 & 1.2901 & 0.6361 & $<0.001$ & 31.31 \\
\hline $5.0-5.5$ & 11 & 123.01 & 1.4461 & 0.7510 & $<0.001$ & 32.11 \\
\hline $5.5-6.0$ & 12 & 214.51 & 1.0717 & 0.6455 & $<0.001$ & 31.45 \\
\hline $6.0-6.5$ & 13 & 181.45 & 1.2319 & 0.7726 & $<0.001$ & 26.54 \\
\hline $6.5-7.0$ & 14 & 116.64 & 1.5464 & 0.8372 & $<0.001$ & 22.38 \\
\hline $7.0-7.5$ & 15 & 114.68 & 1.6536 & 0.8134 & $<0.001$ & 23.45 \\
\hline $7.5-8.0$ & 16 & 165.83 & 1.4242 & 0.7698 & $<0.001$ & 23.25 \\
\hline $8.0-8.5$ & 17 & 103.31 & 1.8288 & 0.8697 & $<0.001$ & 18.49 \\
\hline $8.5-9.0$ & 18 & 148.08 & 1.5218 & 0.8206 & $<0.001$ & 22.69 \\
\hline $9.0-9.5$ & 19 & 211.18 & 1.4783 & 0.6913 & $<0.001$ & 29.89 \\
\hline $9.5-10.0$ & 20 & 208.31 & 1.3137 & 0.8398 & $<0.001$ & 24.15 \\
\hline $10.0-10.5$ & 21 & 213.16 & 1.3137 & 0.6370 & $<0.001$ & 32.35 \\
\hline $10.5-11.0$ & 22 & 121.10 & 2.0261 & 0.8165 & $<0.001$ & 24.89 \\
\hline $11.0-11.5$ & 23 & 118.96 & 2.0280 & 0.7687 & $<0.001$ & 22.58 \\
\hline$>11.5$ & Mean re & ative err & stimation are $>$ & $30 \%$ & & \\
\hline
\end{tabular}


unbiased estimator of the mean $\left(\overline{\bar{D}}_{\mathrm{ts}}\right)$, confidence intervals $\left(H_{1}, H_{\mathrm{u}}\right)$ and the relative error of estimation $\left(\hat{d}_{\mathrm{B}}\right)$ were calculated (using Eqs. 5, 6, 7 and 8).

\section{Results}

The lengths of $P$. abies windfalls without tops ranged from 20.5 to $31 \mathrm{~m}$. In total, 2,389 entomological analyses of $0.5 \mathrm{~m}$-long sections of windfalls were made. In both research seasons, I. typographus infested all investigated trees colonising their entire lengths. The mean I. typographus infestation density of the windfalls in 2008 and 2009 was similar (471.9 and 437.9 maternal galleries $/ \mathrm{m}^{2}$, respectively; standard error was 50.28 in 2008 and 35.80 in 2009). The mean $P$. chalcographus infestation density of windfalls was 59.3 galleries $/ \mathrm{m}^{2}$ in 2008 (standard error was 9.59) and 62.5 galleries $/ \mathrm{m}^{2}$ in 2009 (standard error was 8.00 ). The frequency of other insect species investigated was very low (their total share was less than $1 \%$ of all recorded galleries on the windfalls).

The structure of galleries of I. typographus

The analysis of the galleries made by I. typographus showed a similar structure during both research seasons. Most galleries had two maternal galleries (more than 56\%), less numerous were galleries with one and three maternal galleries $(22.1$ and $18.9 \%$ as well as $20 \%$ and 19.7 in 2008 and 2009, respectively) (Fig. 4).

In 2008 and 2009, the sex ratio in the population of I. typographus colonising windfalls in the investigated stands indicated an almost twofold higher number of females (their share was 67 and $67.5 \%$, respectively). The data presented confirm that the sample population of I. typographus was in the progradation phase.

The analysis of the distribution of I. typographus on P. abies windfalls

The spatial distribution of I. typographus maternal galleries indicates the balanced density of insects of this species along the examined windfalls. Only in the thicker part of the
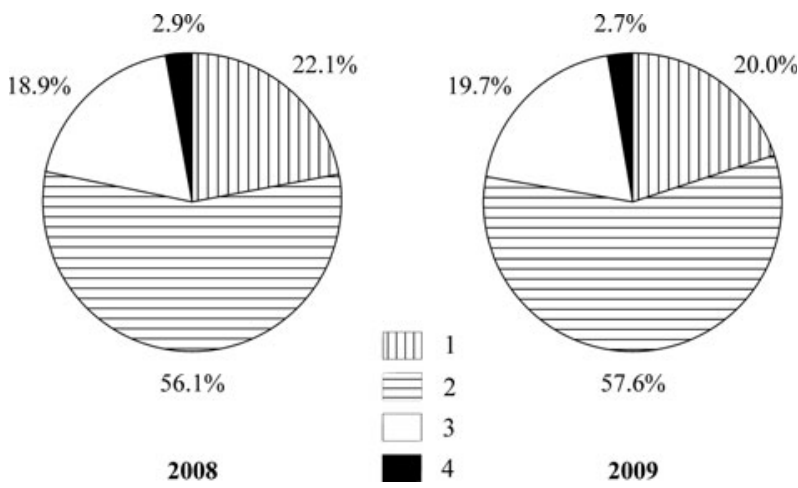

Fig. 4 The structure of galleries of I. typographus in 2008 and 2009. 1 Galleries with one maternal gallery; 2 galleries with two maternal galleries; 3 galleries with three maternal galleries; 4 galleries with four (occasionally five) maternal galleries 


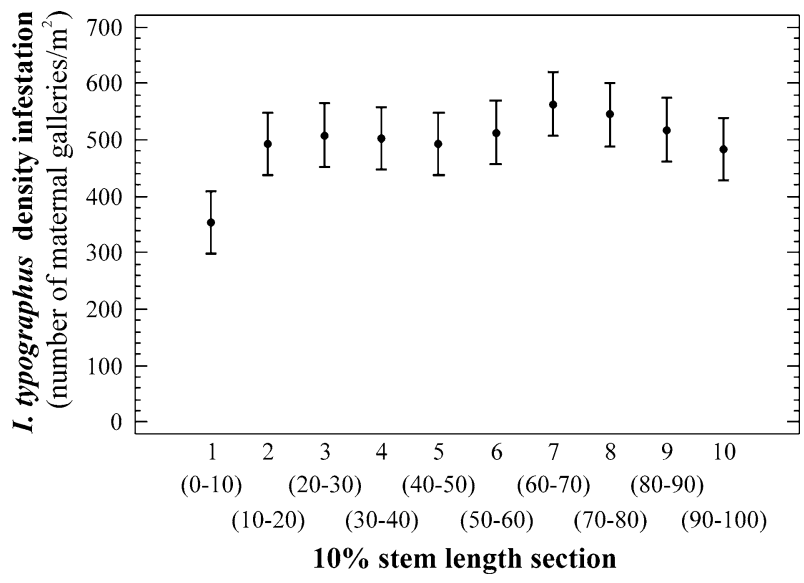

Fig. 5 Distribution of I. typographus on P. abies windfalls in 10\% stem length sections (marked are means and $95.0 \%$ LSD intervals)

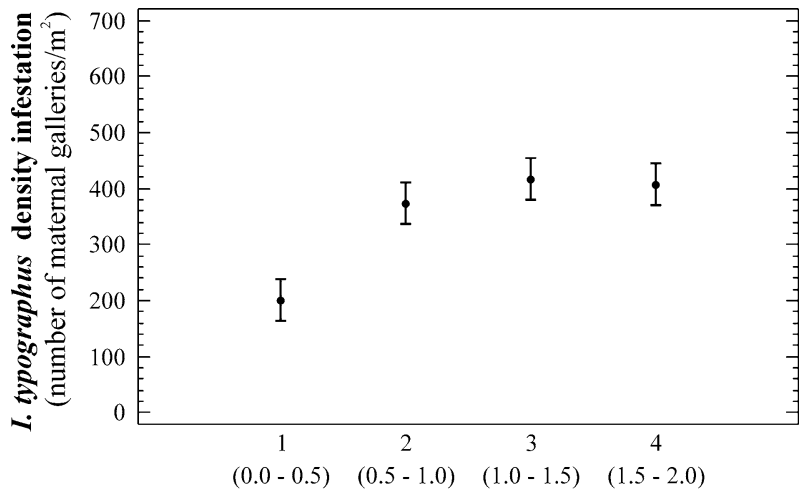

0.5 m-long stem section

Fig. 6 Distribution of I. typographus on P. abies windfalls in the first four $0.5 \mathrm{~m}$-long stem sections (marked are means and $95.0 \%$ LSD intervals)

analysed windfalls (first $10 \%$ section) the density of I. typographus maternal galleries was smaller (ANOVA: $F_{9,490}=1.940, P=0.0445$; post hoc LSD procedure for $\alpha=0.05$ see Fig. 5). The average infestation densities in the remaining $10 \%$ sections were similar and had the values of 483.1 to 563.3 maternal galleries $/ \mathrm{m}^{2}$ (Fig. 5). The observed, lower colonisation of the first $10 \%$ section is the result of low I. typographus frequency in the zone with the nodules and thickest bark, within the first $0.5 \mathrm{~m}$-section (ANOVA: $F_{3,196}=14.3515, P<0.001$; post hoc LSD procedure for $\alpha=0.05$ see Fig. 6). An even distribution of I. typographus on the examined windfalls suggests the existence of a directly proportional relationship between the number of maternal galleries of this insect species in the selected sections and the number of maternal galleries on all stems. 
The relationships between the numbers of I. typographus maternal galleries found in $0.5 \mathrm{~m}$-long stem sections and the total density of the windfall infestation

The results of the correlation and regression analyses show that the most significant correlations were obtained for the 6,7 and 17 th 0.5 m-long stem sections (counting from the butt end) (Table 1). The coefficients of determination for these correlations were highly significant and their values ranged from 0.8459 to 0.8697 . The distribution of the mean relative errors of estimation between the 6th and 23rd sections (with the exception of sections $10,11,12$, and 21 ) did not exceed $30 \%$. The mean relative error of estimation was lowest in sections 17 (18.49\%), 7 (18.90\%), and 6 (20.74\%).

These results suggest that to estimate the total density of I. typographus infestation of the whole $P$. abies windfall, the linear regression equations obtained for the 6,7 and 17 th 0.5 m-long stem sections may be used.

Estimation of I. typographus population density in area investigated-accuracy assessment of the proposed method

On each of 50 windfalls distributed randomly in the area investigated, the total I. typographus infestation density (tree-level analyses) and then the mean total infestation density of the windfall were estimated - the unbiased estimator of the mean and confidence intervals were calculated (stand level analyses). The mean total infestation density of the windfall $\left(\overline{\bar{D}}_{\mathrm{ts}}\right)$ was 440.6 maternal galleries $/ \mathrm{m}^{2}$. The confidence interval at $\alpha=0.05$ for the mean total infestation density of the windfall was from $H_{1}=358.7$ (the lower limit) to $H_{\mathrm{u}}=522.6$ (the upper limit) maternal galleries $/ \mathrm{m}^{2}$. The relative error of estimation $\left(\hat{d}_{\mathrm{B}}\right)$ was $18.6 \%$.

\section{Discussion}

Model evaluation and validation

The proposed method is statistically-based and consists of three main stages, including: (1) selection of all elements or a representative sample of the population of $P$. abies windfalls investigated, (2) assessment of the total density of I. typographus infestation of each of $P$. abies selected stem and (3) estimation of the mean total infestation density of the stem in the area investigated. The emphasis should be put on the necessity of use of all three above mentioned stages of estimation. If we use, for example, only the second stage, the evaluation of I. typographus population density can be highly erroneous. In the absence of an adequate number of $P$. abies windfalls, trap trees can be used. In the large-area method, the methods used during sampling rare populations can be applied to select a representative sample for the windfall population, while remote sensing and aerial photography techniques can be employed to find windthrown gaps (in the surroundings of gaps the windfalls can occur) (e.g. Jackson et al. 2000; Foody et al. 2003).

In most studies (e.g. Jakuš 1998; Göthlin et al. 2000; Eriksson et al. 2005, 2008), the I. typographus population density assessment procedures are limited to the second stage and moreover, are not based on statistics which renders the calculation of estimation errors impossible. These procedures consist of counting I. typographus galleries, maternal galleries or mating chambers in the selected section (sections) of the stem, e.g., on bark strips $15 \times 60 \mathrm{~cm}$ (Eriksson et al. 2005, 2006, 2008), $20 \times 30 \mathrm{~cm}$ (Yamaoka et al. 1997), 
$10 \times 10 \mathrm{~cm}$ (Erbilgin et al. 2006) in size, or on the bark pieces removed from the entire stem circumference and of a length not exceeding $0.5 \mathrm{~m}$ taken from different stem parts (Jakuš 1998; Grodzki 2004; Kolk 2004).

The most important stage in the proposed method is the second stage, allowing quick, accurate and minimally invasive estimation of the total density of infestation of selected windfalls by I. typographus.

The I. typographus infestation density on fresh windfalls is strongly dependent on the abundance of such material: (1) in the case of high number of windfalls and low population density, the population is dispersed; (2) in the case of low number of windfalls and high population density, the population is concentrated on accessible windfalls and the attack on standing trees occurs (e.g. Grodzki et al. 2006a). The data collected from windfalls occurring in low population density are not directly comparable with those collected from windfalls occurring in high population density. The proposed method need to be adapted to the local conditions.

The analogically developed linear regression functions were also successfully used to evaluate the stem total density of other insect species: Tomicus piniperda occurring on Pinus sylvestris stems as well as Cryphalus piceae and Pityokteines curvidens associated, inter alia, with A. alba (Borkowski and Podlaski 2005; Podlaski and Borkowski 2009a, b).

Application to analysis of I. typographus population density

The forests growing in the Świętokrzyskie Mountains were subjected to the fluctuating actions of many stress factors (e.g. wind) causing an intensive mortality of trees (Podlaski 2008a). In the investigated stands, I. typographus colonised all $P$. abies windfalls in the first year after damage from wind. The studies indicate that the colonisation of trees damaged by wind can take up to 2 years (Annila and Petäistö 1978; Göthlin et al. 2000; Eriksson et al. 2005). The length of the colonisation period depends on various climatic factors such as the degree of insolation on the sites with windfalls and population size (Jakuš 1998). In the Świętokrzyskie Mountains intermediate-scale disturbances increased the number of windfalls (Podlaski 2008b). The occurrence of a large number of windfalls creates favourable conditions for the development of bark beetles and spread of the population in the stand. The following year, when the number of windfalls is lower, the attacks on standing trees are found to be stronger (Lindelöw and Schroeder 1998; Göthlin et al. 2000; Grodzki et al. 2006b). In 2008, the breeding base for bark beetles in the Świętokrzyskie Mountains was extended to include fresh windfalls from the late autumn of 2007 and early spring of 2008. In 2009, I. typographus attacked fresh windfalls from the late autumn of 2008 , as well as single standing trees both on exposed sites and trees in the forest interior where insolation was reduced. A similar I. typographus progradation pattern was observed in other areas affected by wind damage both in Poland (e.g. Grodzki 2004) and in other European countries (e.g. Forster 1998; Lindelöw and Schroeder 1998, 2001; Göthlin et al. 2000).

The studies show that with a high availability of breeding material (e.g. a large number of broken trees and high stumps), the windfalls whose roots have contact with the ground are less attacked by I. typographus and colonised mainly in the second year after wind damage (Lekander 1955; Butovitsch 1971; Göthlin et al. 2000). Due to the partially retained contact of tree roots with the ground, the windfalls maintain humidity for a longer time, thus their resistance to beetle attacks is also maintained. With the low availability of the breeding material suitable for colonisation and high population numbers of the I. typographus, the windfalls whose roots retain the contact with the ground are also heavily attacked in the first year after wind damage (Göthlin et al. 2000). 
The investigated I. typographus population is in the progradation phase as evidenced by the sex ratio indicating an approximately twofold higher number of females in the population. The study by Lobinger (1996) shows that during the progradation phase this index increased far beyond 50\%, while during the retrogradation phase it drops to below $50 \%$. It can therefore be assumed that in the investigated stands there is a real risk of I. typographus outbreak. Eventually, the weather conditions in subsequent years may be the factor deciding of the recurrence of damage from wind. The I. typographus population which is in the progradation phase requires continuous and accurate monitoring of its numbers.

\section{Implications for conservation and forest management}

This method may be employed in research models constructed on the basis of environmental variables (taking into account the I. typographus population density estimated on the basis of maternal galleries) used, for example, as a tool for assessing the risk of infestation of windfalls and attack on standing trees (Eriksson et al. 2005; Netherer and Nopp-Mayr 2005; Baier et al. 2007).

The estimation of I. typographus population density requires counting of maternal galleries in individual stem sections of $P$. abies windfalls. In managed forests, trap trees may be used for this purpose, while in nature reserves and national parks only windfalls should be used. The procedure for the estimation of the total density of infestation of selected sample stems requires debarking and counting of maternal galleries in a stem section situated between 2.5 and $3.0 \mathrm{~m}$, or between 3.0 and $3.5 \mathrm{~m}$, or between 8.0 and $8.5 \mathrm{~m}$ along the stem, measuring from the butt-end. This gives an estimation of $I$. typographus population size without the need to fell trees. In the authors' opinion, such interference is acceptable under special permission, even in the strictly protected areas of nature reserves or national parks.

In managed forests, conservation-oriented forestry is only gradually introduced and implemented. Conservation-oriented forestry aims to maintain intact populations of forest organisms by improving the conservation value of managed forests (Gibb et al. 2006a, b). In this situation, the question arises whether I. typographus should be treated as an undesirable element. In conservation-oriented forestry, the determination of the role of I. typographus in a specified time and area has an impact upon the basic and most important decision to be made: whether to apply treatments that may reduce the population size of this insect species. But the answer to this question, as well as the determination of the method of anticipated pest control, the time of carrying protective treatments and the area subject to the treatments is possible only when accurate monitoring of the population dynamics of I. typographus is conducted. Therefore, in the case of I. typographus a continuous monitoring of the population of this bark beetle species should be consistently carried out. The proposed method for assessing the numbers of I. typographus can be used for accurate estimation of the population size of this bark beetle during monitoring. This method may supplement, in the specific situations, surveys applied in order to avoid the I. typographus outbreaks; for example, in $P$. abies stands affected in the past by human activity and in which permanent damage from wind were recorded.

\section{Conclusions}

Ips typographus plays a very important part in forest ecosystems with $P$. abies, and therefore an accurate, statistically-based method for estimating its population density is 
necessary. It is considered a bioindicator of forest health and vitality, ecosystem engineers and keystone species. No accurate method for estimating the population density of this species has been developed so far. A quick and accurate evaluation of I. typographus population density would facilitate monitoring of forest health and vitality and help determine the role of this species in a forest ecosystem.

The proposed method may be used to estimate the population density of I. typographus in nature reserves, national parks and managed forests, especially for scientific purposes.

The presented study needs to be validated in pure and mixed $P$. abies stands with recognised I. typographus infestations.

It should be noted that in conservation-oriented forestry the role of I. typographus is considered flexible. Depending on the local natural, economic and social conditions, decisions are made whether to apply or not apply control treatments to this bark beetle species. Therefore, the accurate and quick evaluation of I. typographus population density is important, as only on this basis appropriate and relevant decisions can be made.

Monitoring of I. typographus population density using the proposed method could be conducted in $P$. abies stands in which I. typographus outbreaks potentially occur (e.g. in mature $P$. abies stands established by planting and damaged by wind). The I. typographus population dynamics analysed in this way will also facilitate rational management under conservation-oriented forestry.

The proposed method need to be calibrated and adjusted to the local conditions of infestation of $P$. abies windfalls. Basing on the analysis of the relationships between the number of I. typographus maternal galleries in selected $0.5 \mathrm{~m}$-long stem sections and the total density of stem infestation, local linear regression functions can be developed, thus increasing the accuracy of the method.

This method with the analogically developed linear regression functions could be tested on the other cambio- and xylophagous insect species in forests growing in all climatic zones. The applicability of this method probably depends on specific requirements of individual insect species.

Acknowledgments We are indebted to the reviewers for their helpful comments and apt remarks that led to significant improvements in the article.

Open Access This article is distributed under the terms of the Creative Commons Attribution Noncommercial License which permits any noncommercial use, distribution, and reproduction in any medium, provided the original author(s) and source are credited.

\section{References}

Anderbrant O (1990) Gallery construction and oviposition of the bark beetle Ips typographus (Coleoptera: Scolytidae) at different breeding densities. Ecol Entomol 15:1-8

Annila E, Petäistö RL (1978) Insect attack on windthrown trees after the December 1975 storm in western Finland. Commun Inst For Fenn 94:1-24

Baier P, Pennerstorfer J, Schopf A (2007) PHENIPS-a comprehensive phenology model of Ips typographus (L.) (Col. Scolytidae) as a tool for hazard rating of bark beetle infestation. For Ecol Manag 249:171-186

Bakke A (1989) The recent Ips typographus outbreak in Norway-experiences from a control program. Holarct Ecol 12:515-519

Barański S, Krysztofik E (1978) Dotychczasowa gospodarka leśna na obszarze Świętokrzyskiego Parku Narodowego i otuliny. Świętokrzyski Park Narodowy, Bodzentyn

Borkowski A, Podlaski R (2005) A method of estimation of the total density of infestation of Scots pine stems by the larger pine shoot beetle (Tomicus piniperda L.). Fol For Pol Ser A 47:25-32 
Bouget C, Duelli P (2004) The effects of windthrow on forest insect communities: a literature review. Biol Conserv 118:281-299

Buse J, Schröder B, Assmann T (2007) Modelling habitat and spatial distribution of an endangered longhorn beetle-a case study for saproxylic insect conservation. Biol Conserv 137:372-381

Butovitsch V (1971) Undersökningar över skadeinsekternas uppträdande i de stormhärjade skogarna i mellersta Norrlands kustland ären 1967-69. Inst Skogszool Rapp Upps 8:1-204

Christiansen E, Waring RH, Berryman AA (1987) Resistance of conifers to bark beetle attack: searching for general relationships. For Ecol Manag 22:89-106

Cochran WG (1977) Sampling techniques. Wiley, New York

Dutilleul P, Nef L, Frigon D (2000) Assessment of site characteristics as predictors of the vulnerability of Norway spruce (Picea abies Karst.) stands to attack by Ips typographus L. (Col., Scolytidae). J Appl Entomol 124:1-5

Eidmann HH (1992) Impact of bark beetles on forests and forestry in Sweden. J Appl Entomol 114:193-200

Erbilgin N, Krokene P, Christiansen E, Zeneli G, Gershenzon J (2006) Exogenous application of methyl jasmonate elicits defenses in Norway spruce (Picea abies) and reduces host colonisation by the bark beetle Ips typographus. Oecologia 148:426-436

Eriksson M, Pouttu A, Roininen H (2005) The influence of windthrow area and timber characteristics on colonization of wind-felled spruces by Ips typographus (L.). For Ecol Manag 216:105-116

Eriksson M, Lilja S, Roininen H (2006) Dead wood creation and restoration burning: implications for bark beetles and beetle induced tree deaths. For Ecol Manag 231:205-213

Eriksson M, Neuvonen S, Roininen H (2007) Retention of wind-felled trees and the risk of consequential tree mortality by the European spruce bark beetle Ips typographus in Finland. Scand J For Res 22:516-523

Eriksson M, Pouttu A, Roininen H (2008) Ips typographus (L.) attack on patches of felled trees: "windfelled" vs. cut trees and the risk of subsequent mortality. For Ecol Manag 255:1336-1341

Faccoli M, Stergulc F (2008) Damage reduction and performance of mass trapping devices for forest protection against the spruce bark beetle, Ips typographus (Coleoptera Curculionidae Scolytinae). Ann For Sci 65:309

Foody GM, Jackson RG, Quine CP (2003) Potential improvements in the characterisation of forest canopy gaps caused by windthrow using fine resolution multispectral data: comparing hard and soft classification techniques. For Sci 49:444-454

Forster B (1998) Storm damages and bark beetle management: how to set priorities. In: Grodzki W, Knížek M, Forster B (eds) Methodology of forest insect and disease survey in Central Europe. IUFRO_Forest Research Institute, Warsaw, pp 161-165

Gibb H, Hjältén J, Atlegrim O, Hilszczański J, Ball JP, Johansson T, Danell K (2006a) Effects of landscape composition and substrate availability on saproxylic beetles in boreal forests: a study using experimental logs for monitoring assemblages. Ecography 29:1-14

Gibb H, Pettersson RB, Hjältén J, Hilszczański J, Ball JP, Johansson T, Atlegrim O, Danell K (2006b) Conservation-oriented forestry and early successional saproxylic beetles: responses of functional groups to manipulated dead wood substrates. Biol Conserv 129:437-450

Gilbert M, Nageleisen LM, Franklin A, Grégoire JC (2005) Post-storm surveys reveal large-scale spatial patterns and influences of site factors, forest structure and diversity in endemic bark-beetle populations. Landsc Ecol 20:35-49

Göthlin E, Schroeder LM, Lindelöw Å (2000) Attacks by Ips typographus and Pityogenes chalcographus on windthrown spruces (Picea abies) during the two years following a storm felling. Scand J For Res 15:542-549

Grodzki W (2004) Some reactions of Ips typographus (L.) (Col.: Scolytidae) to changing breeding in a forest decline area in the Sudeten Mountains, Poland. J Pest Sci 77:43-48

Grodzki W (2007) Wykorzystanie pułapek feromonowych do monitoringu populacji kornika drukarza w wybranych parkach narodowych w Karpatach. Pr IBL, Rozpr Monogr 8:1-128

Grodzki W, Loch J, Armatys P (2006a) Występowanie kornika drukarza Ips typographus L. W uszkodzonych przez wiatr drzewostanach świerkowych masywu Kudłonia w Gorczańskim Parku Narodowym. Ochr Besk Zach 1:125-137

Grodzki W, Jakuš R, Lajzová E, Sitková Z, Mączka T, Škvarenina J (2006b) Effects of intensive versus no management strategies during an outbreak of the bark beetle Ips typographus (L.) (Col.: Curculionidae, Scolytinae) in the Tatra Mts. in Poland and Slovakia. Ann For Sci 63:55-61

Grodzki W, Kosibowicz M, Mączka T (2008) Skuteczność wystawiania pułapek feromonowych na kornika drukarza Ips typographus (L.) w sąsiedztwie wiatrowałów i wiatrołomów. Leś Pr Bad 69:365-370

Grodzki W, Turčáni M, Jakuš R, Hlásny T, Raši R, McManus ML (2010) Bark beetles in the Tatra Mountains. International research 1998-2005-an overview. Fol For Pol Ser A 52:114-130 
Haase P (1995) Spatial pattern in ecology based on Ripley's K-function: introduction and methods of edge correction. J Veg Sci 6:575-582

Hedgren PO, Schroeder LM (2004) Reproductive success of the spruce bark beetle Ips typographus (L.) and occurrence of associated species: a comparison between standing beetle-killed trees and cut trees. For Ecol Manag 203:241-250

Inoue A (2006) A model for the relationship between form-factors for stem volume and those for stem surface area in coniferous species. J For Res 11:289-294

Jackson RG, Foody GM, Quine CP (2000) Characterising windthrown gaps from fine spatial resolution remotely sensed data. For Ecol Manag 135:253-260

Jakuš R (1998) Patch level variation on bark beetle attack (Col., Scolytidae) on snapped and uprooted trees in Norway spruce primeval natural forest in endemic conditions: species distribution. J Appl Entomol 122:65-70

Kolk A (ed) (2004) Instrukcja ochrony lasu. CILP, Warszawa

Lekander B (1955) Skadeinsekternas uppträdande i de av januaristormen 1954 drabbade skogarna. Medd fr Statens Skogsforskningsinst 45:1-35

Lieutier F (2004) Host resistance to bark beetles and its variations. In: Lieutier F, Day KR, Battisti A, Gregoire JC, Evans HF (eds) Bark and wood boring insects in living trees in Europe: a synthesis. Kluwer Academic Publishers, London, pp 135-180

Lindelöw A, Schroeder LM (1998) Spruce bark beetle (Ips typographus) attack within and outside protected areas after a stormfelling in November 1995. In: Grodzki W, Knížek M, Forster B (eds) Methodology of forest insect and disease survey in Central Europe. IUFRO_-Forest Research Institute, Warsaw, pp 177-180

Lindelöw A, Schroeder M (2001) Spruce bark beetle, Ips typographus (L.), in Sweden: monitoring and risk assessment. J For Sci 47:40-42

Lobinger G (1996) Variations in sex ratio during an outbreak of Ips typographus (Col., Scolytidae) in Southern Bavaria. Anz Schädl Pflanz Umweltschutz 69:51-53

Mazur S (2001) Kornik drukarz w parkach narodowych - pożądany gość czy wróg. Parki Nar Rezerw Przyr 2:89-96

Müller J, Bußler H, Goßner M, Rettelbach T, Duelli P (2008) The European spruce bark beetle Ips typographus (L.) in a national park-from pest to keystone species. Biodivers Conserv 17:2979-3001

Netherer S, Nopp-Mayr U (2005) Predisposition assessment systems (PAS) as supportive tools in forest management-rating of site and stand-related hazards of bark beetle infestation in the High Tatra Mountains as an example for system application and verification. For Ecol Manag 207:99-107

Peltonen M (1999) Windhrowns and dead-standing trees as bark beetle breeding material at forest-clearcut edge. Scand J For Res 14:505-511

Podlaski R (2005) Inventory of the degree of tree defoliation in small areas. For Ecol Manag 215:361-377

Podlaski R (2008a) Characterization of diameter distribution data in near-natural forests using the Birnbaum-Saunders distribution. Can J For Res 38:518-527

Podlaski R (2008b) Dynamics in Central European near-natural Abies-Fagus forests: does the mosaic-cycle approach provide an appropriate model? J Veg Sci 19:173-182

Podlaski R, Borkowski A (2009a) Method for estimating density of Cryphalus piceae (Ratz.) brood galleries using a regression model. J Appl Entomol 133:402-409

Podlaski R, Borkowski A (2009b) Estimating stem infestation density of Pityokteines curvidens (Germ.) on windfalls: a statistical approach. J Pest Sci 82:357-365

Ripley BD (1981) Spatial statistics. Wiley, New York

Schelhaas MJ, Nabuurs GJ, Schuck A (2003) Natural disturbances in the European forests in the 19th and 20th centuries. Glob Change Biol 9:1620-1633

Schröter H (1999) Ausbreitung des Borkenkäferbefalls in Bannwäldern Baden-Württembergs. In: Wulf A, Berendes KH (eds) Forstschutzprobleme in Nationalparken und Naturschutzgebieten. Biol Bundesanst Land-Forstw, Mitt 362, Berlin, pp 63-79

Seidl R, Rammer W, Jäger D, Lexer MJ (2008) Impact of bark beetle disturbance (Ips typographus) on timber production and carbon sequestration in different management strategies under climate change. For Ecol Manag 256:209-220

Seidl R, Schelhaas MJ, Lindner M, Lexer MJ (2009) Modelling bark beetle disturbances in a large scale forest scenario model to assess climate change impacts and evaluate adaptive management strategies. Reg Environ Change 9:101-119

Simberloff D (1998) Flagships, umbrellas, and keystones: is single species management passé in the landscape era? Biol Conserv 83:247-257

StatSoft (2004) Statistica, version 6.1. StatSoft, Inc., Tulsa

Sun X, Yang Q, Sweeney JD, Gao C (2006) A review: chemical ecology of Ips typographus (Coleoptera, Scolytidae). J For Res 17:65-70 
Thompson SK (2002) Sampling. Wiley, New York

Wermelinger B (2004) Ecology and management of the spruce bark beetle Ips typographus-a review of recent research. For Ecol Manag 202:67-82

Wermelinger B, Duelli P, Obrist MK (2002) Dynamics of saproxylic beetles (Coleoptera) in windthrow areas in alpine spruce forests. For Snow Lansc Res 77:133-148

Wichmann L, Ravn HP (2001) The spread of Ips typographus (L.) (Coleoptera, Scolytidae) attacks following heavy windthrow in Denmark, analysed using GIS. For Ecol Manag 148:31-39

Wolfram S (2003) The mathematica book. Wolfram Media/Cambridge University Press, Cambridge

Yamaoka Y, Wingfield MJ, Takahashi I, Solheim H (1997) Ophiostomatoid fungi associated with the spruce bark beetle Ips typographus f. aponicus in Japan. Mycol Res 101:1215-1227 